\title{
Promoting the Occupational Well-being of Teachers for the Comenius Program
}

\author{
Terhi Saaranen ${ }^{1}$, Kerttu Tossavainen ${ }^{1}$, Eva Ryhänen ${ }^{2} \&$ Hannele Turunen $^{1}$ \\ ${ }^{1}$ Department of Nursing Science, University of Eastern Finland, Kuopio, Finland \\ ${ }^{2}$ The Well-being Projects at School (Comenius Project "Feeling Good, Tools for the Teacher Well-being"), Espoo, \\ Finland \\ Correspondence: Terhi Saaranen, Department of Nursing Science, University of Eastern Finland, P.O.BOX 1627, \\ FI-70211Kuopio, Finland. Tel: 358-500-940-242. E-mail: terhi.saaranen@uef.fi
}

Received: April 17, 2013

Accepted: May 9, 2013

Online Published: May 10, 2013

doi:10.5430/ijhe.v2n2p159

URL: http://dx.doi.org/10.5430/ijhe.v2n2p159

\begin{abstract}
This article reports the development and results of a project within the Comenius program to promote teachers' occupational well-being, in which Finnish, Irish, Italian, and German school communities participated between 2003 and 2006. The project made use of participatory action research, in which the occupational well-being of staff was developed in accordance with the ideas and operational models of the learning organization. The occupational well-being of teachers along with its development requirements were evaluated using a quantitative index questionnaire distributed in four schools in 2004 and 2005. Finnish teachers experienced improvements in the functionality of their work community, based on all of the sum variables measured during the follow-up year. Positive development was less significant in the partner countries. Based on the results of this research and the practical experiences gained through this project, we conclude that it is important to get school staff involved in actions that develop their occupational well-being by encouraging participation and cooperation, develop the pedagogical leadership skills of the school head, and stimulate cooperation between researchers and school staff. In addition, a project coordinator is required; if she/he has good interaction skills and is socially competent, this individual will be a key foundation for the success of the project. This article contains evidence-based information for school staff, school administrators, researchers, health care staff and educators that is valuable for developing the occupational well-being of school staff within the school community. The results gained through this study cannot be generalized, but they can be considered indicative of comparable situations.
\end{abstract}

Keywords: Action research, Learning organization, Teacher, Occupational well-being

\section{Introduction}

In this article, we describe viewpoints and guidelines for developing the occupational well-being of school staff within the school community, based on knowledge gathered from practical situations and research. We describe a case study examining the development of the occupational well-being of school staff in four schools: one in Finland and three partner schools in Italy, Germany, and Ireland, between 2003 and 2006.

The concepts of well-being and occupational well-being have been used very diversely across the literature. In this study, the factors affecting occupational well-being and its promotion were divided into four sections: 1) the worker and work, 2) working conditions, 3) professional competence, and 4) the working community. The initial section includes staff members and their work and describes the health, the psychological and physical work load, the individual resources, and the factors that affect them. In turn, the section about working conditions includes the physical operational environment (physical, chemical and biological factors) and the issue of work safety. The section describing professional competence covers occupational competency as well as options for additional education or training. The section about work community is considered to include areas such as the supervision of work and the organization, leadership, social support, and communication with the staff (Saaranen et al., 2007).

This idea of occupational well-being, consisting of four sections, is consistent with actions that sustain one's capacity to work. This includes methodological and goal-oriented actions, carried out between the employer, employees, and collaborative organizations within the work place, whose purpose is to promote the health and well-being of the members of society who participate in working life. A fairly new concept, termed "actions for occupational well-being", is used in this study to describe the actions supporting one's ability to work. The process of participatory action research, in which the concept of the learning organization is an essential integral part, was used as the theoretical foundation for this study (see Figure 1: Participatory action research as a framework and an operational model for learning organization in school communities). 


\section{Background}

If organizations, including school communities, are to keep up with constant change and be able to offer high-quality services, they must create the prerequisites for their development into a learning organization. According to both international and national studies, the work of teachers has changed in recent years. Teachers have reported changes in the content of their teaching work, with the introduction of new teaching and learning methods, as well as an increase in administrative tasks (Ballet \& Kelchtermans, 2009). These new challenges and tasks that teaching staff now undertake are responsible for difficulty in managing everyday work. When this happens, changes and problems may cause the atmosphere in the work community to deteriorate and increasing exhaustion among teachers. Moreover, considerable improvement to the physical structure of schools is required, such as school buildings (which may have sustained damage due to mold and moisture, for example) and the areas where teachers and other staff work (such as problems of adequate ventilation of teaching premises, acoustics, teaching aids and furniture) (Fernandes \& Rocha, 2009; Perkiö-Mäkelä, 2010; Sahakian, White, Park, Cox-Ganser, \& Kreiss, 2008).

The need for change can stem from many different sources, such as working life, decision-making authorities in education policy and changes to standard procedures (Commission of the European Communities, 2007; Government Program, 2011; Ministry of Education, 2008). In order for institutions to survive these changes, it is vital for staff to be able to cope with the modifications occurring in their work place. Educational organizations must understand how they can increase the involvement of staff and utilize their knowledge in the development of the organization (Bowen, Ware, Rose, \& Powers, 2007). Participation and learning form the basis for the development of the occupational well-being of staff, and this in turn has an effect on the learning, health and well-being of children and young adults (Roffey, 2008; Van Petegem, Aelterman, Van Keer, \& Rosseel, 2008).

It is a basic premise that only flexible, adaptive and profitable educational organizations can succeed in situations where rapid change takes place. Reforming school activities requires the staff to be willing to cooperate in new and varying ways that promote and strengthen participation, a sense of community, innovations, and mutual support (Bowen et al., 2007). In a learning organization, development actions that take the effects of changes into consideration also require a willingness within the organization to experiment and take risks, to freely exchange knowledge and ideas, to understand the tasks of other professionals, and successful communication between the whole staff and management (Frankl \& Gibbons-Carr, 2001; Friedman, Friedman, \& Pollack, 2005; Layzell \& Chanall, 2010).

The concept of learning organization can be considered to be a principal tool for organizations and those trying to meet the demands of their working life. The learning that occurs within work places includes a combination of official, unofficial and everyday learning, and the acquisition of new information occurs on individual, group, and organizational levels. Competent workers are essential and valuable resources for their organization, particularly in the current economic and social climate (Saru, 2007). The role of the leader is also significant in a learning organization. He or she must be able to define and adjust his/her style of leadership (transformational, transactional, or ambidextrous) to suit both current and emerging situations so that learning will occur in the most efficient ways on the different organizational levels (Busic, Robinson, \& Ramburuth, 2010). As a result of learning that occurs in the work place, the practices designed to promote the occupational well-being of staff can be improved, and innovations can be applied and further developed in other organizations or departments. In such cases, innovations that have already been developed and tested are also transferred to different areas.

By utilizing the model of a learning organization, one can begin carrying out development actions for a school community using participatory action research. The process of understanding a learning organization (e.g. Yekutiel \& Orthner, 2007) is similar to the process of using action research. Bowen et al., (2006, 2007) researched the actions of an organization that learns in similar ways to educational establishments and the sentiments that this learning includes (see Bowen et al., 2007; appendix). Among other elements, the importance of team work (team orientation), the employees' appreciation of the ideas and opinions of others and their willingness to try new things (innovation) and share their ideas (information flow) were highlighted. Furthermore, involvement, tolerance of error, and results orientation were also emphasized as being important (Bowen et al., 2007).

Similarly, cooperation, empowerment, life experiences, the involvement of participants and the creation of something new through critical analysis and reflection have been highlighted as important aspects of action research (Baum, MacDougall, \& Smith, 2006; Tossavainen, Turunen, \& Vertio, 2005). The goal of action research is to empower participants in their own lives. Action research also serves as an excellent means to help researchers agree on practical issues (Glasson, Chang, \& Bidewell, 2008) and actions to take with communities (Kelly, 2005). Indeed, the idea is that a group starts the research by itself and members of a research group are drawn into it (Burns \& Grove, 2009). For instance, research by Casey (2011) indicates the need for combining practice with academic know-how. Action research builds a bridge between the two worlds by sharing scientific information with the knowledge and life experience used by communities (Savage et al., 2006). This also helps to embed ideas of health promotion into communities, and expands the influences of this information to health promotion practices (Kelly, 2005). Casey (2011) also highlighted the importance of the role of the coordinator in an action research project, since good relationship skills and competences in social interaction are required by the coordinator at different stages of the action research process. 
However, the idea of action research and the philosophy of the learning organization have not been extensively used in the development of the occupational well-being of school staff (e.g. Saaranen, Tossavainen, Turunen, Kiviniemi, \& Vertio 2007; Saaranen et al., 2011). Instead, action research has been used more in areas such as the promotion of children's health in a school community (e.g. Gullan, Feinberg, Freedman, \& Leff, 2009; Khunti et al., 2008; Ozer, Ritterman, \& Wanis, 2010), developing education or improving professional know-how in nursing (Casey, 2007; Casey, 2011; Coetzee, Britton, \& Clow, 2005) or when developing nursing practices (Glasson et al., 2008; Mitchell, Conlon, Armstrong, \& Ryan, 2005; Moore, Crozier, \& Kite, 2011).

Action research has been described as a cyclical process, with slight variations depending on the context of the research and sources (e.g. Casey, 2007; Gallagher, Truglio-Londrigan, \& Levin, 2009; Glasson et al., 2008, Moore et al., 2011). However, the cyclical nature of the process is one of the key ideas behind action research and is created by the process of reflecting, planning, action, observing outcomes, feedback and reflection, and replanning (e.g. Glasson et al., 2008). During an action research project, one must be aware that the research must be flexible if necessary, and that it must fit the demands of its environment and participants. Nonetheless, the research proceeds in a cyclical manner, and one endeavors to improve actions further during the subsequent rounds.

The following case study examines development of the occupational well-being of teachers in a project run as part of the Comenius program. The results and operational models produced by the research are then presented, discussed, and plans for further actions are detailed.

\section{Carrying out the project on the occupational well-being of teachers for the Comenius program from 2003 to 2006}

In 2003, a Finnish school founded the Comenius working group, which started planning and composing an application for a three-year program. The group prepared the project "Feeling good, tools for teachers' well-being" whose purpose was to improve occupational well-being for teachers. The goal was to identify tools and methods for evaluating teachers' occupational well-being and their capacity to cope with their work (see Figure 1).

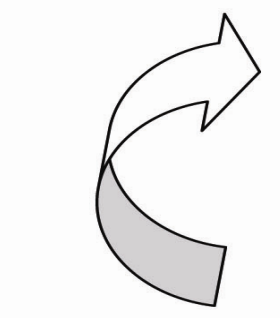

Stage 4: Evaluation: feedback, reflection and replanning (between 2005 and 2006 )

- follow-up survey using the index questionnaire for school staff an updated plan of operations for schoo staffs

- disseminating the results gained from the study (a publication event, a website etc.)

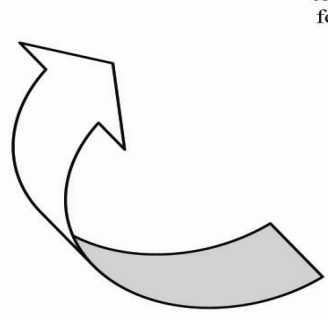

\section{Stage 1: Surveying the starting point (in 2003)}

- a Finnish school founded a Comenius working group - funding was sought from CIMO

- Irish, Italian and German schools joined the project

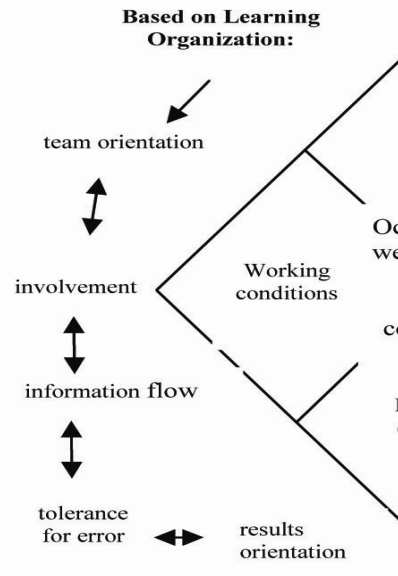

Stage 3: Implementing and observing actions (from 2004 to 2005)

- Index questionnaire on occupational well-being

- in all countries, actions were developed from the starting point according to a shared project plan

- implementation of stress-management afternoon events for teachers, which included lectures,

introductory presentations and discussions in small groups

- in addition, each country had its own plan
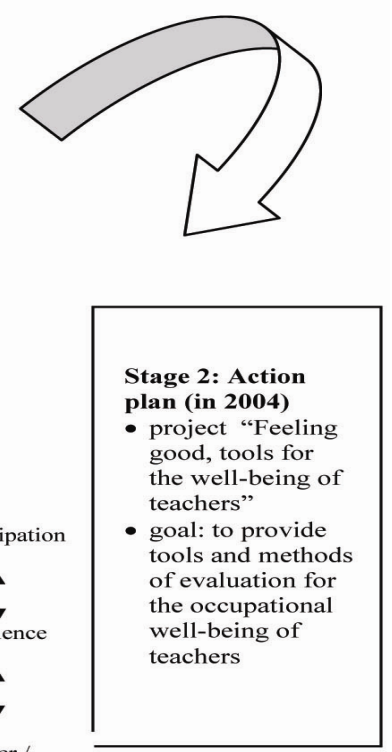

power / participation
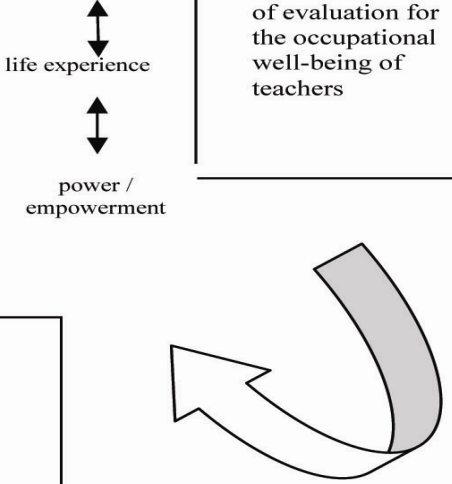

Figure 1. Participatory Action Research as a Framework and an Operational Model for Learning Organization in School Communities 
The project received funding from the Centre for International Mobility and Cooperation (CIMO), whose goal is to promote the internationalization of Finnish society in the areas of education, working life and culture, as well as among young people (Cimo, 2011). CIMO accepted the school's project application to enter its Comenius program, which strives to support cooperation, along with student and staff exchanges, between European schools. This Comenius project, coordinated in Finland, was joined by one school from each of its partner countries: Ireland, Germany and Italy. In each of these partner countries, occupational well-being was developed according to a shared international project plan. One tangible action that all the partner countries shared was a series of afternoon events covering stress-management for teachers that included lectures, introductory presentations and small group discussions. Each school also had its own plans, which varied from country to country.

In 2004, there was some interest in combining the Comenius project with academic research. During this time, the first index questionnaire on occupational well-being for school staff members was developed by a research group at the University of Eastern Finland (known as the University of Kuopio until 2009). The questionnaire was used in all partner countries. The research group from the university was responsible for analyzing and summarizing the results. Summaries of the results from each country were sent to the Finnish Comenius team, which then passed the results to the Comenius working groups in the partner schools. The working groups in each country were responsible for processing the results of the research and for continuing further developmental actions based on the data pertinent to their own school community. Partner meetings between participants in the four countries furthered the development of the project according to its goals, and enabled the identification of differences and similarities between the partner countries. This also enabled the development of new ideas about how teachers could be helped to cope with stress and made to feel comfortable in their work.

The following section describes a case study of the development of occupational well-being in the Finnish school community based on research results.

The research results were disseminated to Finnish schools and discussed in small groups at teachers' meetings (see Figure 1, Stage 3) in accordance with the relevant sections of the content model for promoting occupational well-being in schools (Saaranen et al., 2007). Each group recorded the results of their discussion and these results were presented to others. Developing an affirmative experience of a community at the school and increasing the school staff's involvement to improve occupational well-being acted as the starting points for discussion. The intention was to create interactive situations in which every participant was free to openly discuss issues with others. The interaction and meeting other participants were important, and there was a constant effort to achieve cooperation.

At the Finnish school, the research results and discussions, with additional comments, were compiled on a flip chart, and each participant had the opportunity to comment and include further reflection on any section of the chart. The Finnish Comenius working group then began contemplating how occupational well-being could be developed based upon the research results and comments. The section concerning the work community received a great deal of comments in Finland. There were also many comments about leadership on the flip chart, and these required the school head to be involved systematically in the actions. The head of the school was presented with the material that had been collected, and the following afternoon, at the stress-management event for teachers, the head began with a presentation entitled "What has been done with the issues recorded at the last meeting?" Furthermore, the work community was developed to make the meetings more open for discussion and increasingly interactive, with classroom assistants being better accommodated than previously by including them in well-being events, training and meetings.

In 2005, the research group at the University of Kuopio repeated their research with the use of the index questionnaire about occupational well-being for school staff. After the study, a new program for staff occupational well-being was devised. This incorporated the results of the questionnaire and a plan for the development of occupational well-being. A public event was organized shortly thereafter, so that journalists could also share information on the work that had been completed. Another result of the Comenius project was an extensive website, created to help interested parties follow the progression of the project. The Comenius project "Feeling good, tools for teachers' well-being" was finished in 2006. The year 2007 marked the start of a new Comenius project, which continued promoting actions for well-being at schools together with new partner countries.

The purpose of this study was to describe the well-being of teachers in a Finnish school and schools in the partner countries (Italy, Ireland, and Germany) at the beginning of the project in 2004 and at the follow-up stage in 2005. The goal of this research was to produce descriptive research information that could be used in the development of occupational well-being in schools. The research framework also allowed comparison of the results gathered from the Finnish school with the data from the schools in the partner countries.

\section{The study questions}

1. What was the level of teachers' subjective occupational well-being at their workplace compared to the highest possible level and how did they experience the general well-being of the staff in their working community in 2004 and 2005, at all participating schools? 
2. What kind of experience did the teachers have concerning the actions relating to occupational well-being available to them and the actions available in their working community relating to occupational well-being in 2004 and in 2005, at all participating schools?

3. How did the teachers rate the functionality of their school community in 2004 and 2005 ?

4. How did teachers consider the development needs for improving functionality of the school community were being met in 2004 and 2005 ?

\section{Methods}

\subsection{Questionnaire and Data}

The survey data for the initial and development stages of the research were acquired using the index questionnaire on occupational well-being (Saaranen et al., 2007; 2011). The research population consisted of the teachers of one Finnish school (in 2004, n=36 and in 2005, $\mathrm{n}=41$ ), one Irish school (in 2004, $\mathrm{n}=11$ and in 2005, $\mathrm{n}=10$ ), one Italian school (in 2004, $\mathrm{n}=29$ and in 2005, $\mathrm{n}=32$ ) and one German school (in 2004, $\mathrm{n}=8$ and in 2005, $\mathrm{n}=9$ ). The research framework of this study separated the Finnish teachers into one group and the teachers from the other school communities into a second group. In this paper the latter are hereafter referred to as the teachers in the partner countries. Only the teachers who answered the index questionnaire on occupational well-being in both 2004 and 2005 were considered in this study. This equated to 25 Finnish teachers and 32 teachers from partner countries (Italy $n=19$, Germany $n=5$ and Ireland $n=8$ ). The research questionnaire was realized by the research group in the University of Eastern Finland in cooperation with the coordinator of the Comenius project. The coordinator helped in distributing the questionnaire forms to participants who returned the completed questionnaires to the research group.

The questionnaire was developed by, and tested in, national and international studies (Saaranen et al., 2007, 2011). The original Finnish form had been translated into English and Estonian and had been previously tested in these languages. In this study, the Finnish respondents used the Finnish form and the participants in partner countries the English version. The section of the questionnaire concerning background information consisted of 10 questions with open and classified variables (see Tables 1 and 2). The respondent's satisfaction with their occupational well-being and the available actions for occupational well-being (= actions maintaining one's ability to work) were recorded using four variables on the Likert scale $(1-5 ; 1=$ very poor... $5=$ very good). In addition, by using variables scored on the Likert scale (1-5), the index questionnaire on occupational well-being ("The Well-being at your Work" index questionnaire) was used to help clarify the sections on occupational well-being relating to working conditions, the worker and work, work community and professional competence. The respondents were asked for their opinion on the different areas of occupational well-being using the variables in question $(1=$ totally disagree. $. .5=$ totally agree $)$ and on their view of the developmental needs of these variables $(1=$ requires a lot of development...5 $=$ does not require any development $)$.

\subsection{Data Analyses}

This article reports the results of the analysis performed on the background information (percentages, frequencies, Kruskal-Wallis testing, one-way analysis of variance, and Fisher's exact test), on the state of occupational well-being and of actions supporting working ability (mean and one-way analysis of variance) as well as on teachers' opinions about the functionality of the work community and the development required (sum variables of the working community aspect, mean, SD, one-way analysis of variance, and Cronbach's alpha coefficients). Sum variables (six in total) were formed from the variables in the work community section (questions $30-49$, in total 20 variables) by using item analysis (Polit \& Beck, 2011). There was a strong correlation between the variables relating to opinion and the need for development, and the results of the survey from the years 2004 and 2005. Therefore, the sum variables were constructed so that they remained the same for variables relating to opinion and those relating to need for development, regardless of the time when they had been measured. When forming sum variables, statements were included if removing them would have reduced the Cronbach's alpha value. In tables 4 and 5, the means and standard deviations of individual variables related to these statements are also reported under the sum variables. When the sum variables were defined, five variables were left out. The Cronbach's alpha values of the sum variables were between $0.721-0.942$ (Tables 4, 5).

\subsection{Validity and reliability}

This participatory action research project was carried out in accordance with the ethical principles of The National Advisory Board on Research Ethics (2002), which are described in "Good scientific practice and procedures for handling misconduct and fraud in science" and "Guidelines on Research Ethics", both published by the Academy of Finland (2003). Participation in this study was completely voluntary for the respondents. Before sending out each qualitative questionnaire, written permission was sought from the head of each school. Those participating in this study were given information via a covering letter, and the respondents were offered the opportunity to contact those gathering the data. In 2004 and 2005, each person taking part in the study provided written consent for their participation.

The research data were gathered using ethically sustainable data acquisition methods (Academy of Finland, 2003). The index questionnaire for occupational well-being used in the preliminary stage of the research had been developed and 
tested in national and international studies (Saaranen et al., 2007, 2011). It is not possible to extract personal information about individual respondents through the questionnaire form used for this study, and the anonymity of the respondents is protected so that one cannot identify them from the report on the research findings. In this study, item analysis was used to create six sum variables from individual variables that were significant indicators from the working community section. The Cronbach's alpha values lay between 0.721 and 0.942 (Table 4,5$)$, which can be considered very good (Polit \& Becker, 2011).

The results of this study cannot be widely generalized, as the research data contained information on the teachers from only four schools (25 from the Finnish school and 35 from the partner schools) across four European countries. Although the amount of research material was also small, an attempt was made to increase the reliability of the results from the point of view of development by including in the study only those teachers who responded to the questionnaire at the beginning of the project in 2004 and again at the follow-up stage in 2005 . However, the results suggest trends, and the ideas and the operational model used in this study (see Figure 1) could be applied to developmental work on the occupational well-being of school staff in different schools both nationally and internationally.

\section{Results}

\subsection{Background variables}

The categorical variables from the data are presented in table 1, as percentages and frequencies. The differences between data from Finland and from the partner countries were tested using Fisher's exact test. Analysis of the background variables from Finland and the partner countries showed that there was no statistical significance based on gender, marital status or whether or not the respondent had children. However, nearly half of the Finnish teachers $(45.8 \%)$ were subject-specialist teachers, whereas all of the teachers in the partner countries were primary school teachers. There was also a statistically significant difference in the regularity of employment, as nearly all respondents in the partner countries $(96.9 \%)$ held a permanent position in their work place, compared with $64 \%$ of the teachers in Finland (Table 1).

Table 1. Categorical Background Variables Relating to School Staff in Finland $(n=25)$ and the Partner Countries $(\mathrm{n}=32)$

\begin{tabular}{|c|c|c|c|c|c|}
\hline \multirow[t]{2}{*}{ Background variables } & \multicolumn{2}{|c|}{ Finland } & \multicolumn{3}{|c|}{ Partner countries } \\
\hline & $\mathrm{n}$ & $\%$ & $\mathrm{n}$ & $\%$ & p-value \\
\hline \multicolumn{6}{|l|}{$\overline{\operatorname{Sex}}$} \\
\hline Male & 5 & 20 & 4 & 12.5 & \\
\hline Female & 20 & 80 & 28 & 87.5 & \\
\hline Total & 25 & 100 & 32 & 100 & \\
\hline Fisher's exact test & & & & & 0.485 \\
\hline \multicolumn{6}{|l|}{ Marital status } \\
\hline Married/ & 19 & 79.2 & 18 & 58.1 & \\
\hline \multicolumn{6}{|l|}{ Co-habiting } \\
\hline Unmarried & 5 & 20.8 & 13 & 41.9 & \\
\hline Total & 24 & 100 & 31 & 100 & \\
\hline Fisher's exact test & & & & & 0.148 \\
\hline \multicolumn{6}{|l|}{ Children } \\
\hline Has a child/children & 15 & 60 & 17 & 53.1 & \\
\hline No children & 10 & 40 & 15 & 46.9 & \\
\hline Total & 25 & 100 & 32 & 100 & \\
\hline Fisher's exact test & & & & & 0.604 \\
\hline \multicolumn{6}{|l|}{ Profession } \\
\hline Subject teacher & 11 & 45.8 & 0 & 0 & \\
\hline Primary school teacher & 13 & 54.2 & 32 & 100 & \\
\hline Total & 24 & 100 & 32 & 100 & \\
\hline Fisher's exact test & & & & & 0.000 \\
\hline \multicolumn{6}{|l|}{ Contract type } \\
\hline Permanent & 16 & 64.0 & 31 & 96.9 & \\
\hline Temporary & 9 & 36.0 & 1 & 3.1 & \\
\hline Total & 25 & 100 & 32 & 100 & \\
\hline Fisher's exact test & & & & & 0.003 \\
\hline
\end{tabular}

Note. $\mathrm{p} \leq 0,05$ statistically nearly significant; $\mathrm{p} \leq 0,01$ statistically significant; $\mathrm{p} \leq 0,001$ statistically highly significant 
Table 2 presents the continuous numerical background variables for age, number of staff, number of years in the current work place and the total number of years in the current position. According to the one-way analysis of variance (ANOVA), there was no statistically significant difference between these background variables in the data from Finland or the partner countries. When the testing was performed using the Kruskal-Wallis test, a nearly statistically significant difference in the number of years at the current workplace was obtained ( $\mathrm{p}$-value $=0.039$ ).

Table 2. Numerical Background Variables Relating to School Staff in Finland $(n=25)$ and the Partner Countries $(n=32)$

\begin{tabular}{|c|c|c|c|c|c|c|c|}
\hline \multirow[t]{2}{*}{ Background variables } & \multicolumn{4}{|c|}{ Finland } & \multicolumn{3}{|c|}{ Partner countries } \\
\hline & $\mathrm{n}$ & Mean & SD & $\mathrm{n}$ & Mean & $\mathrm{SD}$ & p-value \\
\hline Age & 24 & 41.92 & 11.92 & 32 & 42.78 & 10.92 & \\
\hline Total & 56 & 42.41 & 11.26 & & & & \\
\hline ANOVA & & & & & & & 0.779 \\
\hline Kruskal-Wallis & & & & & & & 0.685 \\
\hline Number of staff & 23 & 59.30 & 5.07 & 32 & 55.75 & 31.11 & \\
\hline Total & 55 & 57.24 & 23.86 & & & & \\
\hline ANOVA & & & & & & & 0.591 \\
\hline Kruskal-Wallis & & & & & & & 0.224 \\
\hline $\begin{array}{l}\text { Number of years at } \\
\text { current workplace }\end{array}$ & 25 & 8.52 & 11.23 & 32 & 11.01 & 8.09 & \\
\hline Total & 57 & 9.92 & 9.58 & & & & \\
\hline ANOVA & & & & & & & 0.335 \\
\hline Kruskal-Wallis & & & & & & & 0.039 \\
\hline $\begin{array}{l}\text { Total number of } \\
\text { years in current } \\
\text { profession }\end{array}$ & 25 & 14.66 & 12.58 & 32 & 18.51 & 11.37 & \\
\hline Total & 57 & 16.82 & 11.97 & & & & \\
\hline ANOVA & & & & & & & 0.231 \\
\hline Kruskal-Wallis & & & & & & & 0.256 \\
\hline
\end{tabular}

Note. $\mathrm{SD}=$ standard deviation; ANOVA $=$ one-way analysis of variance; $\mathrm{p} \leq 0,05$ statistically nearly significant

\subsection{Occupational well-being and satisfaction with the actions available for occupational well-being}

In 2004, the Finnish teachers considered their subjective occupational well-being at their workplace ("subjective occupational well-being at this workplace compared with the highest level possible") and the occupational well-being of the school community ("general well-being of the staff in my working community") to be slightly less satisfactory than the teachers in the partner countries. However, follow-up data from 2005 indicated that more positive development had taken place on the occupational well-being of Finnish teachers than in any other country (Figure 2). 


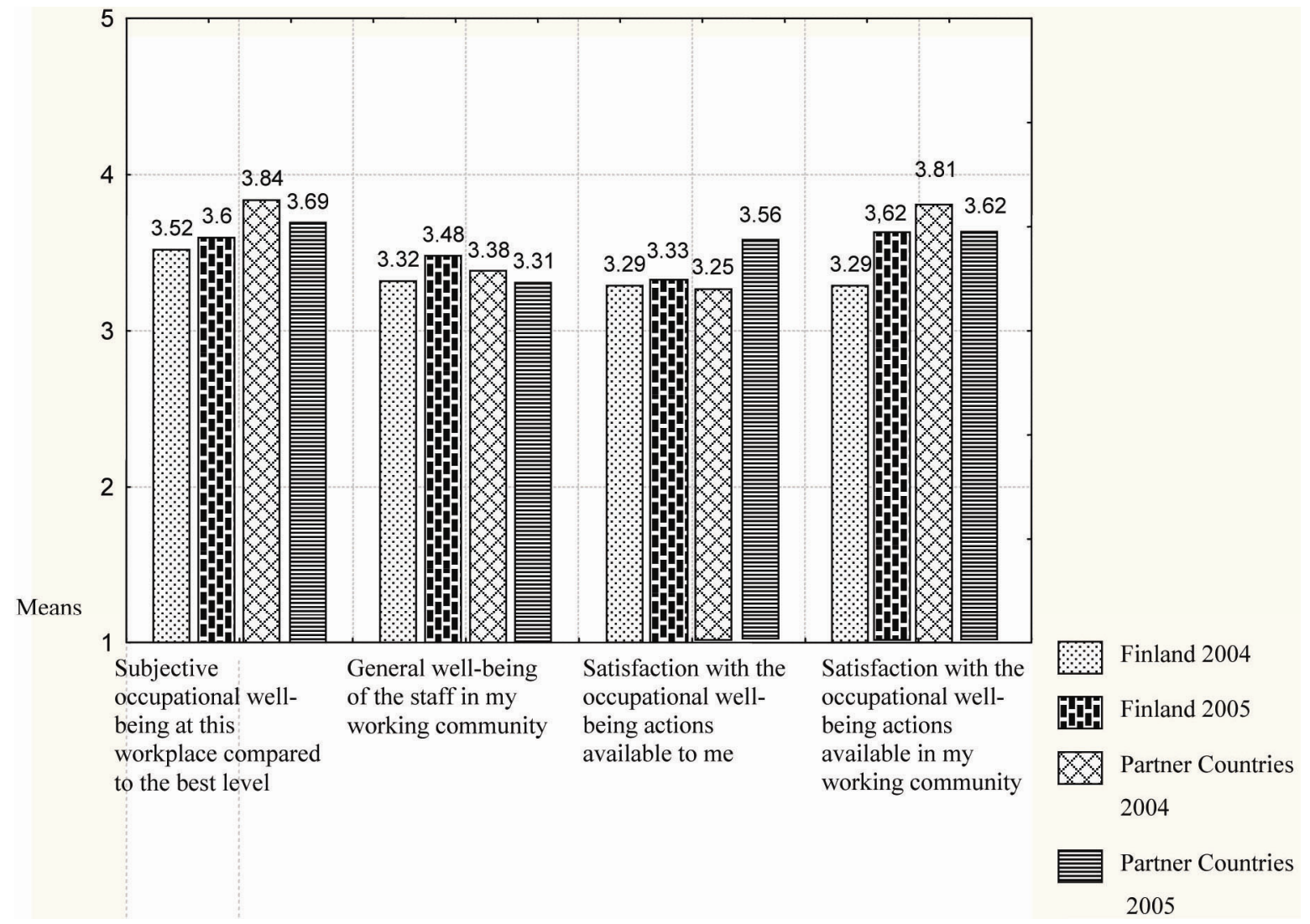

Figure 2. Teachers' Evaluation of their Occupational Well-being and Satisfaction with the Occupational Well-being Actions Available to them (Means) in 2004 and 2005 (Finland: n=25; Partner Countries: n=32)

Based on the averaged Likert scores of respondents' answers, the results collected in 2004 showed that satisfaction with occupational well-being actions was lowest on an individual level (in Finland, the mean was 3.29 and in the partner countries 3.25, see Table 3: Satisfaction with the occupational well-being actions available to me). However, the results also indicate that only a year of participation in the project brought about positive developments. In 2005, the mean value for satisfaction with occupational well-being actions on an individual level was 3.33 in Finland and 3.56 in the partner countries (Figure 2). According to the results from 2004 and 2005 regarding the respondents' satisfaction with occupational well-being actions at the community level, only teachers in the Finnish school reported positive developments (Figure 2). However, one-way analysis of variance indicated that differences between those changes in Finland and the partner countries were not statistically significant.

6.3 Teachers' opinion on the functionality of their school community and development needs for it in 2004 and 2005

The section on work community consisted of six sum variables: 1) work scheduling, the functionality of time management, and sufficient cooperation between different groups of professionals; 2) cooperation between professionals within one's own professional field or subject ("sufficient cooperation between professionals from one's own field"); 3) receiving sufficient information on changes and getting enough support for managing change ("sufficient information on changes, enough support for managing change"); 4) the functionality of relationships between members of the work community; 5) sufficient information, support and help from one's closest supervisor ("sufficient information, support and help from closest supervisor"); and 6) mutual understanding of tasks between co-workers and trust in others' work input. The sum variables were the same in both the section on opinions (Figure 3; Table 3) and in the section on development needs (Figure 4; Table 4), and their Cronbach's alpha values are presented based on the sum variables in tables 3 and 4 . 


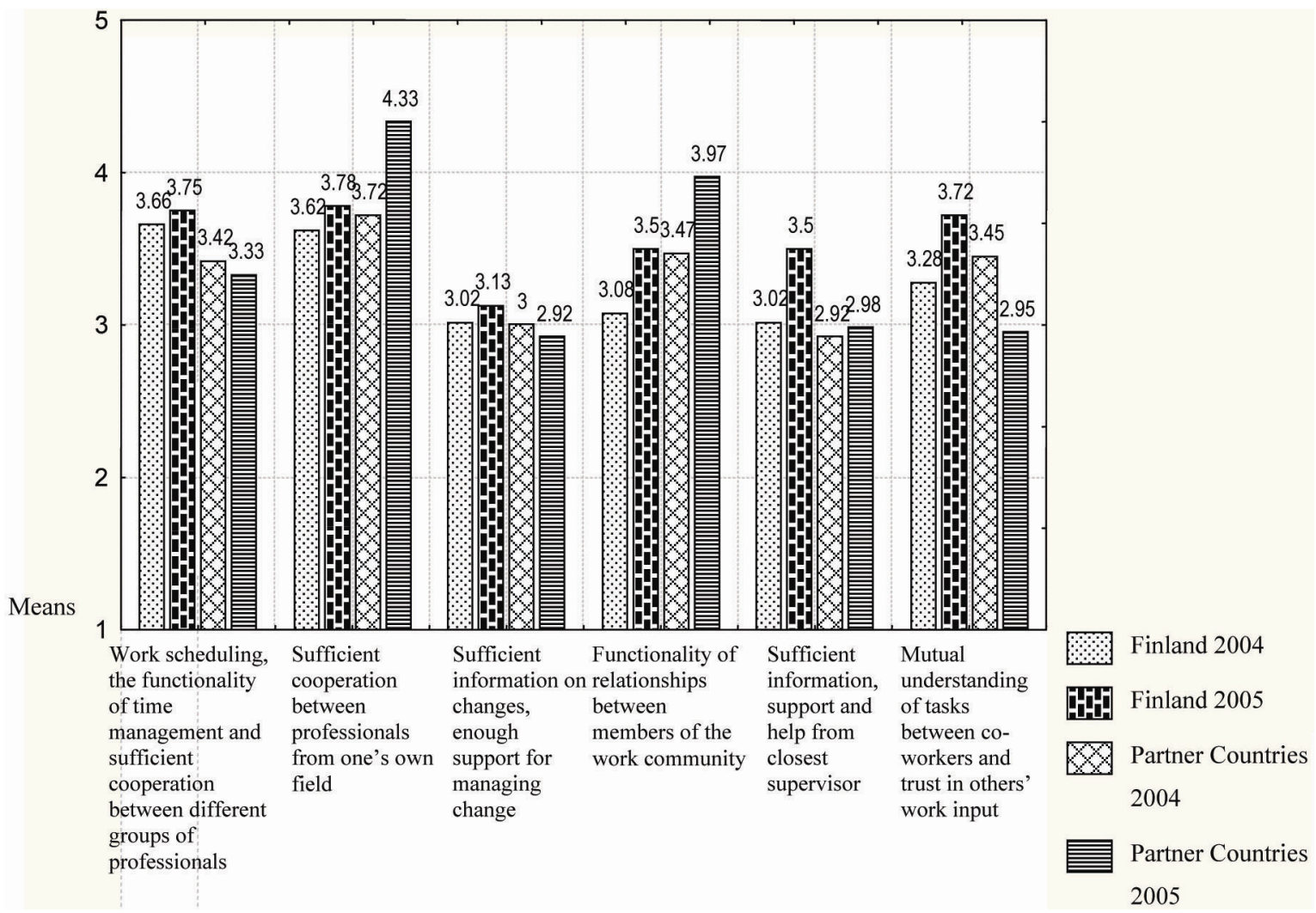

Figure 3. Opinions of Teachers in Finland $(n=25)$ and Partner Countries $(n=32)$ on the Functionality of their Work Community in 2004 and 2005 (Means of the Six Sum Variables)

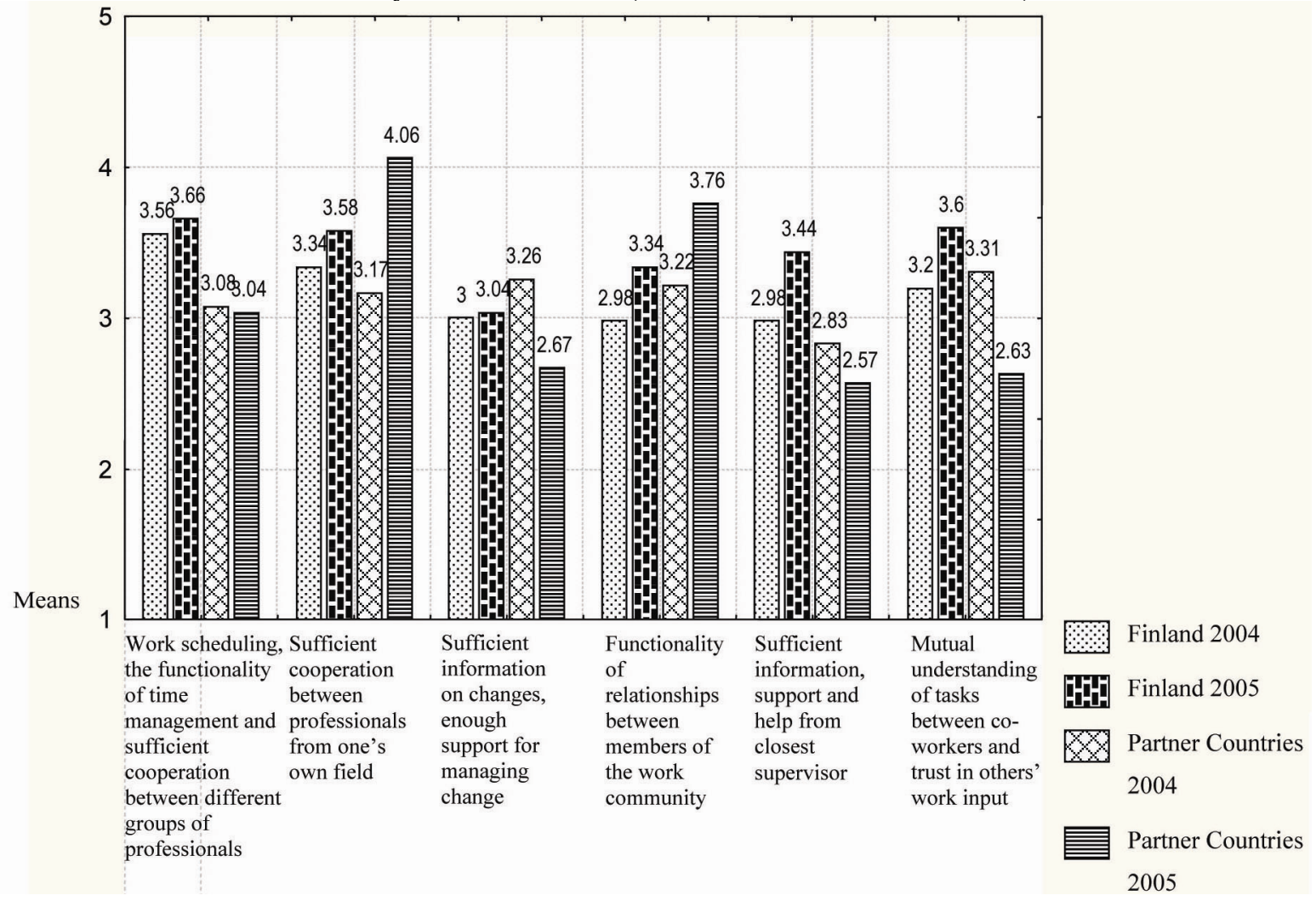

Figure 4. Opinions of Teachers in Finland $(n=25)$ and Partner Countries $(n=32)$ on the Development Needs of the Functionality of their Work Community in 2004 and 2005 (Means of the Six Sum Variables) 
Results indicate that Finnish teachers experienced positive development in all of the sum variables of the work community section. The most significant positive change occurred in the sum variables relating to "sufficient information, support and help from the closest supervisor", "mutual understanding of tasks between co-workers and trust in others' work input" and "functionality of relationships between members of the work community". In the partner countries, the result for the sum variable "mutual understanding of tasks between co-workers and trust in others' work input" declined (in 2004 the mean was 3.45 and in 2005 2.95; see Figure 3). However, there was an increase in the sum variable relating to sufficient cooperation between professionals from one's own field among teachers in Finland and in the partner countries.

Positive development was also apparent when addressing the separate questions about the sum variables relating to "work scheduling, the functionality of time management and sufficient cooperation between different groups of professionals" for teachers in Finland (Table 3). However, the questions designed to elicit information about cooperation between different occupational groups and the appreciation of the respondents' work in their work community revealed that a decline had occurred in the partner countries during the year between the questionnaires.

Table 3. Teachers' Opinions on the Functionality of their Work Community in 2004 and 2005 (Means and Standard Deviations (SDs) of the Six Sum Variables and of Each Individual Variable) in Finland $(n=25)$ and Partner Countries $(n=32)$

\begin{tabular}{|c|c|c|c|c|c|c|c|c|c|c|}
\hline \multirow[t]{3}{*}{$\begin{array}{l}\text { Variables } \\
\text { OPINION }\end{array}$} & \multicolumn{2}{|c|}{ Finland } & \multicolumn{2}{|c|}{ Finland } & \multicolumn{2}{|c|}{$\begin{array}{l}\text { Partner } \\
\text { Countries }\end{array}$} & \multicolumn{2}{|c|}{$\begin{array}{l}\text { Partner } \\
\text { Countries }\end{array}$} & \multirow[t]{2}{*}{ ANOVA } & \multirow{3}{*}{$\begin{array}{l}\text { Cronbach's } \\
\text { Alpha }\end{array}$} \\
\hline & 2004 & & 2005 & & 2004 & & 2005 & & & \\
\hline & Mean & $\mathrm{SD}$ & Mean & SD & Mean & SD & Mean & $\mathrm{SD}$ & p-value & \\
\hline $\begin{array}{l}\text { Work scheduling, the functionality } \\
\text { of time management and sufficient } \\
\text { cooperation between different } \\
\text { groups of professionals }\end{array}$ & 3.66 & 0.60 & 3.75 & 0.67 & 3.42 & 0.94 & 3.33 & 0.95 & 0.348 & 0.769 \\
\hline $\begin{array}{l}\text { I am satisfied with my working time } \\
\text { arrangements }\end{array}$ & 4.04 & 1.04 & 3.96 & 1.22 & 4.03 & 0.86 & 3.34 & 1.38 & & \\
\hline $\begin{array}{l}\text { Organization of work and time use is } \\
\text { good in my working community }\end{array}$ & 3.21 & 0.98 & 3.33 & 0.96 & 3.45 & 1.15 & 3.39 & 1.33 & & \\
\hline $\begin{array}{l}\text { There is sufficient cooperation } \\
\text { between the different occupational } \\
\text { groups }\end{array}$ & 3.39 & 1.03 & 3.43 & 1.08 & 3.32 & 1.05 & 2.74 & 1.29 & & \\
\hline $\begin{array}{l}\text { My work is appreciated in my } \\
\text { working community }\end{array}$ & 3.62 & 0.88 & 3.88 & 0.74 & 3.35 & 1.38 & 2.74 & 1.51 & & \\
\hline $\begin{array}{l}\text { There are enough colleagues' } \\
\text { meetings outside of working hours }\end{array}$ & 3.92 & 1.00 & 4.08 & 1.08 & 2.68 & 1.60 & 3.55 & 1.57 & & \\
\hline $\begin{array}{l}\text { Sufficient cooperation between } \\
\text { professionals from one's own field }\end{array}$ & 3.62 & 0.96 & 3.78 & 0.95 & 3.72 & 1.09 & 4.33 & 0.69 & 0.056 & 0.721 \\
\hline $\begin{array}{l}\text { There is sufficient cooperation } \\
\text { between colleagues teaching } \\
\text { the same field/subject }\end{array}$ & 3.48 & 1.09 & 3.48 & 1.12 & 3.69 & 1.28 & 4.25 & 0.72 & & \\
\hline $\begin{array}{l}\text { I get help and support from my } \\
\text { colleagues when needed }\end{array}$ & 3.76 & 1.13 & 4.08 & 1.00 & 3.75 & 1.14 & 4.41 & 0.88 & & \\
\hline $\begin{array}{l}\text { Sufficient information on changes, } \\
\text { enough support for managing } \\
\text { change }\end{array}$ & 3.02 & 1.08 & 3.13 & 0.84 & 3.00 & 1.37 & 2.92 & 1.26 & 0.510 & 0.843 \\
\hline $\begin{array}{l}\text { I have received enough support to } \\
\text { manage changes at my workplace }\end{array}$ & 3.05 & 1.17 & 3.00 & 0.76 & 3.16 & 1.44 & 3.09 & 1.35 & & \\
\hline $\begin{array}{l}\text { Information about changes in the } \\
\text { working community has been } \\
\text { sufficient }\end{array}$ & 2.92 & 1.18 & 3.25 & 1.19 & 2.84 & 1.32 & 2.75 & 1.48 & & \\
\hline $\begin{array}{l}\text { Functionality of relationships } \\
\text { between members of the work } \\
\text { community }\end{array}$ & 3.08 & 0.99 & 3.50 & 0.99 & 3.47 & 1.34 & 3.97 & 1.22 & 0.777 & 0.869 \\
\hline $\begin{array}{l}\text { Personal relationships between } \\
\text { workers at my workplace are fine }\end{array}$ & 3.16 & 1.03 & 3.56 & 1.00 & 3.71 & 1.30 & 4.00 & 1.29 & & \\
\hline $\begin{array}{l}\text { There is a spirit of 'fair play' at my } \\
\text { workplace } \\
\text { and there is no harassment of workers }\end{array}$ & 3.08 & 1.10 & 3.42 & 1.06 & 3.32 & 1.47 & 4.00 & 1.21 & & \\
\hline $\begin{array}{l}\text { Sufficient information, support and } \\
\text { help from closest supervisor }\end{array}$ & 3.02 & 1.19 & 3.50 & 1.09 & 2.92 & 1.55 & 2.98 & 1.57 & 0.132 & 0.909 \\
\hline $\begin{array}{l}\text { My closest superior gives me enough } \\
\text { information about expectations } \\
\text { concerning my work performance }\end{array}$ & 2.72 & 1.21 & 3.48 & 1.12 & 2.97 & 1.56 & 3.00 & 1.50 & & \\
\hline $\begin{array}{l}\text { My superior gives me help and } \\
\text { support when I need it }\end{array}$ & 3.32 & 1.31 & 3.52 & 1.30 & 2.88 & 1.62 & 2.97 & 1.71 & & \\
\hline $\begin{array}{l}\text { Mutual understanding of tasks } \\
\text { between co-workers and trust in } \\
\text { others' work input }\end{array}$ & 3.28 & 0.96 & 3.72 & 0.75 & 3.45 & 1.27 & 2.95 & 1.36 & 0.001 & 0.833 \\
\hline $\begin{array}{l}\text { There is mutual understanding of } \\
\text { colleagues' work/tasks in my working } \\
\text { community }\end{array}$ & 3.21 & 1.06 & 3.50 & 0.93 & 3.35 & 1.38 & 2.74 & 1.51 & & \\
\hline $\begin{array}{l}\text { There is trust in others' work input in } \\
\text { my working community }\end{array}$ & 3.40 & 0.96 & 3.96 & 0.74 & 3.53 & 1.39 & 3.12 & 1.29 & & \\
\hline
\end{tabular}

Note. ANOVA = one-way analysis of variance ( $p$-value) was used to test whether the changes of means in Finland ( $p \leq 0,05$ statistically nearly significant; $p \leq 0,01$ statistically significant; $p \leq 0,001$ statistically highly significant) were statistically significantly different from those in the partner countries according to the sum variables

Cronbach's Alpha $=$ Cronbach's Alpha for each sum variable 
Respondents generally had corresponding views about the functionality of their work community (Table 3 ) and the needs for development (Table 4) with respect to similar issues. In practice, this means that if issues have improved (see sum variables and individual variables), the perceived need for more development on those issues would have simultaneously decreased. Similarly, the opposite effect was also seen, for example the opinions in the partner countries indicated a deterioration in the sum variable "mutual understanding of tasks between co-workers and trust in others' work input" (Table 3), and respondents correspondingly reported a greater need for development in this area (Table 4).

Table 4. Teachers' Opinions on the Development Needs of the Functionality of their Work Community in 2004 and 2005 (Means and Standard Deviations (SDs) of the Six Sum Variables and to Each Individual Variable) in Finland $(\mathrm{n}=25)$ and in the Partner Countries $(\mathrm{n}=32)$

\begin{tabular}{|c|c|c|c|c|c|c|c|c|c|c|}
\hline \multirow[t]{2}{*}{$\begin{array}{l}\text { Variables } \\
\text { NEED FOR DEVELOPMENT }\end{array}$} & \multicolumn{2}{|c|}{ Finland } & \multicolumn{2}{|c|}{ Finland } & \multicolumn{2}{|c|}{$\begin{array}{l}\text { Partner } \\
\text { Countries } \\
2004\end{array}$} & \multicolumn{2}{|c|}{$\begin{array}{l}\text { Partner } \\
\text { Countries } \\
2005\end{array}$} & \multirow{2}{*}{$\begin{array}{l}\text { ANOVA } \\
\text { p-value }\end{array}$} & \multirow[t]{2}{*}{$\begin{array}{l}\text { Cronbach's } \\
\text { Alpha }\end{array}$} \\
\hline & Mean & SD & Mean & SD & Mean & SD & Mean & SD & & \\
\hline $\begin{array}{l}\text { Work scheduling, the functionality } \\
\text { of time management and sufficient } \\
\text { cooperation between different } \\
\text { groups of professionals }\end{array}$ & 3.56 & 0.66 & 3.66 & 0.74 & 3.08 & 1.07 & 3.04 & 1.21 & 0.423 & 0.827 \\
\hline $\begin{array}{l}\text { I am satisfied with my working time } \\
\text { arrangements }\end{array}$ & 3.88 & 0.95 & 3.83 & 1.17 & 3.26 & 1.43 & 3.26 & 1.53 & & \\
\hline $\begin{array}{l}\text { Organization of work and time use is } \\
\text { good in my working community }\end{array}$ & 3.09 & 0.90 & 3.17 & 0.94 & 2.81 & 1.36 & 3.19 & 1.55 & & \\
\hline $\begin{array}{l}\text { There is sufficient cooperation } \\
\text { between the different occupational } \\
\text { groups }\end{array}$ & 3.30 & 0.97 & 3.35 & 1.07 & 3.08 & 1.08 & 2.40 & 1.32 & & \\
\hline $\begin{array}{l}\text { My work is appreciated in my working } \\
\text { community }\end{array}$ & 3.42 & 0.97 & 3.71 & 0.81 & 3.15 & 1.51 & 2.52 & 1.58 & & \\
\hline $\begin{array}{l}\text { There are enough colleagues' meetings } \\
\text { outside of working hours }\end{array}$ & 3.88 & 0.88 & 4.08 & 1.04 & 3.08 & 1.60 & 3.50 & 1.68 & & \\
\hline $\begin{array}{l}\text { Sufficient cooperation between } \\
\text { professionals from one's own field }\end{array}$ & 3.34 & 1.09 & 3.58 & 0.97 & 3.17 & 1.44 & 4.06 & 1.09 & 0.670 & 0.893 \\
\hline $\begin{array}{l}\text { There is sufficient cooperation } \\
\text { between colleagues teaching the same } \\
\text { field/subject }\end{array}$ & 3.32 & 1.03 & 3.36 & 1.11 & 3.15 & 1.52 & 3.85 & 1.26 & & \\
\hline $\begin{array}{l}\text { I get help and support from my } \\
\text { colleagues when needed }\end{array}$ & 3.36 & 1.32 & 3.80 & 1.00 & 3.19 & 1.47 & 4.27 & 1.12 & & \\
\hline $\begin{array}{l}\text { Sufficient information on changes, } \\
\text { enough support for managing } \\
\text { change }\end{array}$ & 3.00 & 1.11 & 3.04 & 0.82 & 3.26 & 1.48 & 2.67 & 1.37 & 0.049 & 0.874 \\
\hline $\begin{array}{l}\text { I have received enough support to } \\
\text { manage changes at my workplace }\end{array}$ & 3.10 & 1.18 & 2.86 & 0.79 & 3.15 & 1.43 & 2.88 & 1.48 & & \\
\hline $\begin{array}{l}\text { Information about changes in the } \\
\text { working community has been } \\
\text { sufficient }\end{array}$ & 2.83 & 1.17 & 3.17 & 1.05 & 3.30 & 1.66 & 2.48 & 1.50 & & \\
\hline $\begin{array}{l}\text { Functionality of relationships } \\
\text { between members of the work } \\
\text { community }\end{array}$ & 2.98 & 1.04 & 3.34 & 0.98 & 3.22 & 1.52 & 3.76 & 1.52 & 0.616 & 0.925 \\
\hline $\begin{array}{l}\text { Personal relationships between } \\
\text { workers at my workplace are fine }\end{array}$ & 2.92 & 1.08 & 3.36 & 1.00 & 3.35 & 1.44 & 3.88 & 1.51 & & \\
\hline $\begin{array}{l}\text { There is a spirit of 'fair play' at my } \\
\text { workplace, and there is no harassment } \\
\text { of workers }\end{array}$ & 3.08 & 1.14 & 3.33 & 1.09 & 3.23 & 1.63 & 3.77 & 1.51 & & \\
\hline $\begin{array}{l}\text { Sufficient information, support and } \\
\text { help from closest supervisor }\end{array}$ & 2.98 & 1.20 & 3.44 & 1.00 & 2.83 & 1.64 & 2.57 & 1.65 & 0.008 & 0.942 \\
\hline $\begin{array}{l}\text { My closest superior gives me enough } \\
\text { information about expectations } \\
\text { concerning my work performance }\end{array}$ & 2.80 & 1.19 & 3.48 & 1.12 & 2.89 & 1.65 & 2.59 & 1.65 & & \\
\hline $\begin{array}{l}\text { My superior gives me help and support } \\
\text { when I need it }\end{array}$ & 3.16 & 1.31 & 3.40 & 1.16 & 2.78 & 1.70 & 2.56 & 1.70 & & \\
\hline $\begin{array}{l}\text { Mutual understanding of tasks } \\
\text { between co-workers and trust in } \\
\text { others' work input }\end{array}$ & 3.20 & 0.94 & 3.60 & 0.76 & 3.31 & 1.42 & 2.63 & 1.50 & 0.001 & 0.924 \\
\hline $\begin{array}{l}\text { There is mutual understanding of } \\
\text { colleagues' work/tasks in my working } \\
\text { community }\end{array}$ & 3.21 & 1.02 & 3.38 & 1.01 & 3.15 & 1.51 & 2.52 & 1.58 & & \\
\hline $\begin{array}{l}\text { There is trust in others' work input in } \\
\text { my working community }\end{array}$ & 3.24 & 0.97 & 3.84 & 0.75 & 3.48 & 1.40 & 2.74 & 1.46 & & \\
\hline
\end{tabular}

Note. ANOVA = one-way analysis of variance ( $p$-value) was used to test whether the changes of means in Finland ( $p \leq 0,05$ statistically nearly significant; $p \leq 0,01$ statistically significant; $p \leq 0,001$ statistically highly significant) were statistically significantly different from those in the partner countries according to the sum variables

Cronbach's Alpha $=$ Cronbach's Alpha for each sum variable 
In summary, Finnish teachers experienced improvements in the functionality of their work community based on all of the sum variables when issues were evaluated according to opinions (Table 3 ) and the need for development (Table 4) during the follow-up year. There was also positive development in the partner countries, but it was not as significant, and some areas can be said to have deteriorated. Indeed, in the case of the partner countries, it can be concluded that collaboration with members of staff from within one's own field or subject was reported to have improved and relationships between staff members were considered to be good. Particular deficiencies along with subjects that needed development appeared in the areas of cooperation between different professional groups and there was both a lack of understanding of others' work tasks and insufficient trust in others' work input in the work community. During the follow-up stage, receiving information, support and help from one's superior clearly improved in Finland (where the mean in 2004 was 3.02 but had increased in 2005 to 3.50), whereas no substantial change occurred in this area in the partner countries (the mean rose from 2.92 in 2004 to 2.98 in 2005).

Indeed, the one statistically significant difference in the changes in mean values between Finland and the partner countries was apparent in the sum variables relating to "sufficient information, support and help from closest supervisor" based on the need for development (Table 4) and "mutual understanding of tasks between co-workers and trust in others' work input", based on both the section on opinions (Table 3) and the section regarding the need for development (Table 4).

\section{Discussion}

7.1 Developing occupational well-being of school staff - participatory action research as a framework and operational model for learning organization in school communities

As a participatory action research project, this study examined how school communities could begin developing the occupational well-being of school staff. This can be accomplished by recognizing the need for development and work-based learning or by seeking innovations outside one's own organization (=international networking in this project). The operation models and new innovations that are found to work well could then be shared with other similar organizations. Action research and the ideas and occupational models of the learning organization offer tools to help with this issue (see Figure 1) (e.g. Baum et al., 2006; Bowen et al., 2006, 2007).

Developing the occupational well-being of school staff requires careful planning, and implementation that takes into account the situation at hand and, in particular, ensures that those impacted by the changes are involved in the process. The research section of this study had the purpose to particularly cater for the development work of occupational well-being of staff. It has been possible to use the study results to find out about occupational well-being conditions in schools and to verify practices and methods that have been considered good. These practices can then also be recommended to be used in similar situations where occupational well-being is developed in school communities. Spreading new practices and methods of occupational well-being must be based on evidence, and this also encourages project participants to be involved in development work.

A questionnaire that had already been developed (Saaranen et al., 2007) and the data it helped to provide for this study provided a good foundation for development work. The questionnaire consisted of a section concerning the respondents' background, a section with questions mapping the respondents' general well-being at work and their contentment with occupational well-being actions, and questions about the four sets of factors (the worker and work, working community, professional competence and working conditions) that were used to examine the occupational well-being of school staff in more detail. This article only reported the results of one of these four sections, working community, as it would not have been possible to publish the results on all sections (the worker and work, working conditions, professional competence, and the working community) in the same article due to their scope. Moreover, this project had the particular aim of developing communality in schools, and, therefore, the results from the working community section and the development actions related to it were a particular interest. The backgrounds of those offering data, in other words the teachers in the Finnish school $(\mathrm{n}=25)$ and the teachers in the partner countries $(\mathrm{n}=32)$, were similar, which allowed the use of a comparative approach (Tables 1,2).

The results of this study indicate that the teachers in the partner countries considered their own occupational well-being as well as that of their working community to be slightly better than the teachers in the Finnish school during the preliminary stage of the research. However, the results collected at the follow-up stage in 2005 indicated positive development to have taken place in both the teachers' occupational well-being and their satisfaction with the available occupational well-being actions; this was the case particularly for the Finnish school community (Figure 2). Similar positive development was apparent for the subject of the working community, again especially in the Finnish school (Figures 3, 4; Tables 3, 4). The following paragraphs concentrate on the factors that appear to be particularly significant for the development of the occupational well-being of school staff. 
Forcing employees into situations of change is usually problematic, and it is therefore important to make them part of the actions by involving them and maintaining active cooperation. Among other things, this study utilized a "flip chart method" in the Finnish school, a method that the teachers considered to have increased cooperation and interaction. The method appears to be successful for developing team orientation, involvement, information flow, tolerance of error and result orientation, all of which Bowen et al. (2007) found to be significant actions for a learning organization). The "flip chart method" was, however, only used in the Finnish school community during this project. The experiences gained though this method were positive according to Finnish teachers, and this view is also supported by the strong positive development of the results in the working community section of the questionnaire. Results in this working community area were also primarily favorable in the partner countries, but substantial improvement appeared to be required in the cooperation between different groups of professionals in these countries. Conversely, the Finnish school invested in this area, for instance by making learning assistants more involved in the development of the staff's occupational well-being. The results from the Finnish school indicated that the most significant change occurred in the sum variables related to the relationships between members of staff in the working community, in understanding the work tasks of others and trusting their work input, and in the information, support and help received from one's supervisor.

One of the central factors for the successful development of the occupational well-being of staff in an educational organization was found to be the correct type of pedagogical leadership, which led to a positive improvement in development of occupational well-being, particularly in the Finnish school. The style of leadership significantly affects the team's learning and thus also impacts the group's performance. A leader must be able to use different styles of leadership (transformational, transactional or ambidextrous) according to the learning needs of the organization (Busic et al., 2010). The head of the school must be competent in leading development actions or delegating the authority to carry out actions and continue development work to others, such as a group promoting the occupational well-being of school staff. This kind of team can be established in any school community, thus ensuring that actions dealing with staff-related issues are not the sole responsibility of the head of the school or individual teachers (Saaranen et al., 2012).

In this Comenius project, each country had its own Comenius group whose task was to promote health in their own school. Experiences of those involved in this project, supported by research results, suggest that methods of cooperation that engage their participants and involve a great deal of interaction were more successfully used by the Finnish Comenius group. For example, the "flip chart method" was only used by the staff in the Finnish school. Carrying out this method required active participation from the staff, and the school head's backing was needed to support this approach and to act on the development issues thus highlighted. During the development project, the head of the Finnish school was encouraged to use new kinds of cooperative methods, and thus gained experience in using such, previously unknown, leadership techniques.

The proficient interaction and social skills of the project coordinator are also significant in an action research project (Casey, 2011). The coordinator can be a researcher in the action research project or an employee in the participating working community, such as any other teacher, but not the school head. In this action research project, an elementary teacher from the Finnish school acted as the coordinator for the entire, international Comenius project encompassing four countries. Her high-quality interaction skills played a positive, significant role in her own school's occupational community, the school communities in the partner countries and in the research group.

This project succeeded in bringing researchers and practitioners together in accordance with the ideology of action research (Casey, 2011; Savage et al., 2006). The coordinator (the elementary school teacher in the Finnish school mentioned above) launched the initiative for cooperation between the research group from the university and the project, and the research group followed this by bridging the gap between practical and academic knowledge. The fact that the academic research group was responsible for employing and analyzing the index questionnaires for occupational well-being allowed the school staff to focus their energy on the development of occupational well-being both within their own school community and between the partner countries. Cooperation between school staff and university researchers was carried out in an organic and well-planned manner in this project.

The feedback received from the project coordinator strongly corroborates the need for rapid reaction to evaluation results (here findings from analysis of the index questionnaire for occupational well-being used in 2004 and 2005) in successful, cyclical action research. If one does not use the data gathered by the evaluation system to initiate reconstructive actions, only follow-up can be achieved. Further, if one notices that some essential factors have not been adequately taken into consideration when developing actions to promote the occupational well-being of school staff, and plans are not revised to address detected inadequacies, the process of planning and implementation has not been 
thoroughly structured. It is important to intervene in, and react to, the issues that need development according to the evaluation data as soon as the project timetable allows. If the necessary changes are not implemented in time, they may not produce any results. However, it is noteworthy that it is impossible to enforce all development actions at once, and there should therefore be scheduling and prioritization even with newly-identified goals and development actions. It is also essential for the whole staff to be aware of these goals and actions (e.g. Bowen et al., 2007). There must be transparency in the development actions, and empowerment of the staff who, through their life experiences, can create new approaches through critical thinking and reflection (Baum et al., 2006; Tossavainen et al., 2005). In this endeavor, learning is equally significant, be it at an individual level, in a team or as part of the whole working community (for further discussion, see contributions such as Bowen et al., 2006, 2007; Saru, 2007).

In our case study, the results gathered from the Finnish school and the partner schools at the beginning of the study in 2004 and the follow-up stage in 2005 were discussed together in each of the school communities that took part in the project. The Comenius project involving the Finnish and partner schools ended in 2006, therefore there are no follow-up data on the targets for development that were identified through this research from the partner countries after the end of this project. However, evaluation of the development actions that targeted occupational well-being at the Finnish school has continued, and the most recent evaluation for school staff was conducted, again with the use of the index questionnaire for occupational well-being, in 2009. These results will be reported in a separate publication. However, the results that have been gathered indicate that the developmental work for the occupational well-being of the school's staff has continued.

\section{Conclusions}

School communities face constant change, which means that they must take care of their staff and the development of their staff's occupational well-being. The process of participatory action research offers a solution to this challenge by suggesting the idea of the learning organization as an essential, integral feature (see Figure 1: Participatory action research as a framework and an operational model for learning organization in school communities). Based on the results of this research and the practical experiences gained through this project, the following issues were identified, which should be considered when dealing with the occupational well-being of school staff:

1) It is important to get school staff involved in the actions that develop occupational well-being by facilitating participation and cooperation (see also Bowen et al., 2007; Tossavainen et al., 2005). Methods that increase collaboration and interaction should be utilized in the school community (e.g. the "flip chart method" that was used in the Finnish school in this project).

2) The school head must have suitable pedagogical leadership skills as these play an important role: the leader must be able to utilize different management styles according to the needs of the school community (see also Busic et al., 2010).

3) Cooperation between researchers and the school staff increases the organization of development actions and allows the school staff to concentrate their energy on developmental work, whilst the researchers are responsible for tasks such as the collection of data at the preliminary and follow-up stages. In addition, the development goals and procedures that emerge must be placed in an order of importance and timetables must be constructed to implement the procedures and meet the goals (see also Casey, 2011; Savage et al., 2006).

4) A project coordinator with proficient interaction skills and social competence is a key foundation for the success of such a project (see also Casey, 2011).

\section{References}

Academy of Finland. (2003). Guidelines on research ethics. [Online] Available: http://www.aka.fi/Tiedostot/Tiedostot/Julkaisut/Suomen\%20Akatemian\%20eettiset\%20ohjeet\%202003.pdf

Baum, F., MacDougall, C., \& Smith, D. (2006). Participatory action research. Journal of Epidemiology and Community Health, 60(10), 854-857. http://dx.doi:10.1136/jech.2004.028662

Ballet, K., \& Kelchtermans, G. (2009). Struggling with workload: Primary teachers' experiences of intensification. Teaching and Teacher Education, 25(8), 1150-1157. http://dx.doi.org/10.1016/j.tate.2009.02.012

Bowen, G. L., Rose, R. A., \& Ware, W. B. (2006). The reliability and validity of the school success profile learning organization measure. Evaluation and Program Planning, 29(1), 97-104. http://dx.doi.org/10.1016/j.evalprogplan.2005.08.005 
Bowen, G. L., Ware W. B., Rose, R. A., \& Powers, J. D. (2007). Assessing the functioning of schools as learning organizations. Children \& Schools, 29(4), 199-208. http://dx.doi.org/10.1093/cs/29.4.199

Burns, N. \& Grove, S. (2009). The practice of nursing research. Appraisal, synthesis and generation of evidense $\left(6^{\text {th }}\right.$ ed.). St Louis: Saunders Elsevier.

Busic, T., Robinson, L., \& Ramburuth, P. (2010). Effects of leadership style on team learning. Journal of Workplace Learning, 22(4), 228-248. http://dx.doi.org/10.1108/13665621011040680

Casey, M. (2011). Interorganisational partnership arrangements: A new model for nursing and midwifery education. Nurse Education Today, 31(3), 304-308. http://dx.doi.org/ 10.1016/j.nedt.2010.11.011

Casey, D. (2007). Using action research to change health-promoting practice. Nursing and Health Sciences, 9(1), 5-13. http://dx.doi.org/10.1111/j.1442-2018.2007.00297.x

Cimo. (2011). Centre for International Mobility CIMO. [Online] Available: http://www.cimo.fi/

Coetzee, M., Britton, M., \& Clow, S.E. (2005). Finding the voice of clinical experience: Participatory action research with registered nurses in developing a child critical care nursing curriculum. Intensive and Critical Care Nursing, 21(2), 110-118. http://dx.doi.org/10.1016/j.iccn.2004.07.010

Comission of the European Communities. (2007). Communication from the commission to the council and the European parliament. Improving the quality of teacher education. Brussels, 3.8.2009. COM (2007) 392 final. [Online] Available: http://ec.europa.eu/education/com392_en.pdf

Fernandes, M. H., \& Rocha, V. M. (2009). Impact of the psycholocial aspects of work on the quality of life of teachers. Revista de Brasileira Psiquiatria, 31(1), 15-20.

Frankl, S. N., \& Gibbons-Carr, M. (2001). Creating a school without walls and building a learning organization: A case study. Journal of Dental Education, 65(11), 1253-1263.

Friedman, H. H., Friedman, L. W., \& Pollack, S. (2005). Transforming a university from a teaching organization to a learning organization. Review of Business, 26(3), 31-36.

Gallagher, L. P., Truglio-Londrigan, M., \& Levin, R. (2009). Partnership for healthy living: An action research project. Nurse Reseacher, 16(2), 7-27.

Glasson, J. B., Chang, E. M. L., \& Bidewell, J. W. (2008). The value of participatory action research in clinical nursing practice. International Journal of Nursing Practice, 14(1), 34-39. http://dx.doi.org/10.1111/j.1440-172X.2007.00665.x.

Governmet Programme. (2011). Programme of the Finnish Government. Prime Minister's Office Finland.

[Online] Available: http://www.vn.fi/hallitus/hallitusohjelma/pdf332889/220611hallitusohjelma_en.pdf

Gullan, R. L., Feinberg, B. E., Freedman, M. A., Jawad, A., \& Leff, S. S. (2009). Using participatory action research to design an intervention integrity system in the urban schools. School Mental Health, 1(3), 118-130. http://dx.doi.org/10.1007/s12310-009-9006-9

Kelly, P. J. (2005). Practical suggestions for community interventions using participatory action research. Public Health Nursing, 22(1), 65-73. http://dx.doi.org/10.1111/j.0737-1209.2005.22110.x

Khunti, K., Stone, M. A., Bankart, J., Sinfield, P., Pancholi, A., Walker, S., ... Davies, M. J. (2008). Primary prevention of type-2 diabetes and heart disease: Action research in secondary schools serving an ethnically diverse UK population. Journal of Public Health, 30(1), 30-37. http://dx.doi.org/doi:10.1093/pubmed/fdm078

Layzell, S., \& Chahal, P. (2010). Evaluation of a multiprofessional learning organization: use of a questionnaire to investigate the learning experiences of a group of undergraduate pharmacy students attached to primary care. Education for Primary Care, 21(6), 376-384.

Ministry of Education. (2008). Education and research 2007-2012. Development plan. Ministry of Education publication 2088:11. [Online] http://www.minedu.fi/export/sites/default/OPM/Julkaisut/2008/liitteet/opm11.pdf

Mitchell, E. A., Conlon, A. M., Armstrong, M., \& Ryan, A. A. (2005). Towards rehabilitative handling in caring for patients following stroke: A participatory action research project. International Journal of Older People Nursing in association with Journal of Clinical Nursing, 14(3a), 3-12. http://dx.doi.org/10.1111/j.1365-2702.2005.01143.x 
Moore, J., Crozier, K., \& Kite, K. (2012). An action research approach for developing research and innovation in nursing and midwifery practice: building research capacity in one NHS foundation trust. Nurse Education Today, 32(1), 39-45. http://dx.doi.org/10.1016/j.nedt.2011.01.014

Ozer, E. J., Ritterman, M. L., \& Wanis, M. G. (2010). Participatory action research (PAR) in middle school: Opportunities, constraints, and key process. The American Journal of Community Psychology, 46(1/2), 152-166. http://dx.doi.org/ 10.1007/s10464-010-9335-8

Perkiö-Mäkelä, M. (2010). Koulutus (Education). In T. Kauppinen, R. Hanhela, J. Kandolin, A. Karjalainen, A. Kasvio, M. Perkiö-Mäkelä, E. Priha, J. Toikkanen, \& A. Viluksela (Eds.), Työ ja terveys Suomessa 2009 (Work and Health in Finland 2009) (pp. 234-238, Työterveyslaitos, Helsinki, Sastamala: Vammalan kirjapaino Oy.

Polit, D. F., \& Beck, C. T. (2011). Nursing research. Generating and assessing evidence for nursing practice ( $\left.9^{\text {th }} \mathrm{ed}\right)$. Philadelphia: Lippincott Williams \& Wilkins.

Roffey, S. (2008). Emotional literacy and the ecology of school wellbeing. Educational and Child Psychology, 25(2), 29-39.

Saaranen, T., Tossavainen, K., Turunen, H., Kiviniemi, V., \& Vertio, H. 2007. Occupational wellbeing of school staff members: A structural equation model. Health Education Research, 22(2), 248-260. http://dx.doi.org/ doi:10.1093/her/cyl073

Saaranen, T., Sormunen, M., Streimann, K., Pertel, T., Hansen, S., Varava, L., Lepp, K., Turunen, H., \& Tossavainen, K. (2012). Occupational well-being of school staff and maintenance of their ability to work in Finland and Estonia - focus on the school community and professional competence. Health Education, 112(3), 236-255. http://dx.doi.org/10.1108/09654281211217777

Sahakian, N. M., White, S. K., Park, J-H., Cox-Ganser, J. M., \& Kreiss, K. (2008). Identification of mold and dampness-associated respiratory morbidity in 2 schools: Comparison of questionnaire survey responses to national data. Journal of School Health, 78(1), 32-37. http://dx.doi.org/ 10.1111/j.1746-1561.2007.00263.x

Saru, E. (2007). Organizational learning and HRD: How appropriate are they for small firms? Journal of European Industrial Training, 31(1), 36-51. http://dx.doi.org/10.1108/03090590710721727

Savage, C. L., Xu, Y., Lee, R., Rose, B. L., Kappesser, M., \& Anthony, J. S. (2006). A case study in the use of community-based participatory research in public health nursing. Public Health Nursing, 23(5), 472-478. http://dx.doi.org/10.1111/j.1525-1446.2006.00585.x

Tossavainen, K., Turunen, H., \& Vertio, H. (2005). Collaboration as a learning and research method in promotional and participatory action research in the Finnish ENHP Schools. In S. Clift \& B. B. Jensen (Eds.), The health promoting school: International advances in theory, evaluation and practice (pp. 271-290). Copenhagen: Danish University Press.

Yekutiel, S., \& Orthner, K. D. (2007). Implementing organizational learning in schools: Assessment and strategy. Children \& Schools, 29(4), 243-246. http://dx.doi.org/10.1093/cs/29.4.243

Van Petegem, K., Aelterman, A., Van Keer, H., \& Rosseel, Y. (2008). The influence of student characteristics and interpersonal teacher behaviour in the classroom on student's wellbeing. Social Indicators Research, 85(2), 279-291. http://dx.doi.org/10.1007/s11205-007-9093-7 